\title{
AIRCRAFT FAULT FORECASTING AT MAINTENANCE SERVICE ON THE BASIS OF HISTORIC DATA AND AIRCRAFT PARAMETERS
}

\section{PROGNOZOWANIE USZKODZEŃ STATKÓW POWIETRZNYCH DLA CELÓW OBSŁUGI KONSERWACYJNEJ NA PODSTAWIE ICH PARAMETRÓW ORAZ DANYCH Z EKSPLOATACJ}

\begin{abstract}
Aircraft maintenance and repair organizations (MROs) have to be competitive and attractive for both existing and new customers. The aircraft ground time at MROs should be as short as possible and cost effective without reducing the quality of the work. Process optimization in MROs requires the continuous improvement of processes and the elimination of non-value-added activities during maintenance checks. There is, on the one hand, an obligation to follow the prescribed procedures and, on the other hand, pressure for time and cost reduction. The aircraft servicing process has been analysed according to a lean methodology. The optimization of logistics processes is recognized as the most promising method for reducing the maintenance service time and costs of spare parts. The probability of aircraft faults is calculated on the basis of historic data from previously completed service projects. Aircraft parameters, such as aircraft type, operator, aircraft age, flight hours, flight cycles, engine type and operation location, are taken into consideration in the fault forecasting. The fault probability is used as an indicator for defining a priority list for the accomplishment of jobs included in the aircraft maintenance service. The proposed methodology was validated and confirmed on four different projects.
\end{abstract}

Keywords: aircraft maintenance, fault forecasting, lean methods, machine learning, spare parts logistics.

\begin{abstract}
Organizacje zajmujace się konserwacja i naprawami statków powietrznych (MRO) musza dbać o swoja konkurencyjność i atrakcyjność zarówno dla istniejacych jak i nowych klientów. Czas trwania obstugi naziemnej w MRO powinien być jak najkrótszy a konserwacja powinna pociagać za soba jak najmniejsze koszty, bez konieczności obniżania jakości pracy. Optymalizacja procesów przeprowadzanych w MRO wymaga ciagłego doskonalenia oraz eliminacji nieuzasadnionych czynności przegladowych. Z jednej strony pracownicy MRO musza przestrzegać określonych procedur, z drugiej zaś strony, ciązy na nich presja redukcji czasu $i$ kosztów obstugi. Proces obstugi statku powietrznego analizowano zgodnie z metodologia szczuplego utrzymania ruchu. Optymalizację procesów logistycznych uznaje się za najbardziej obiecujący sposób redukcji czasu obstugi serwisowej oraz kosztów części zamiennych. Prawdopodobieństwo wystapienia uszkodzeń statku powietrznego obliczano na podstawie danych historycznych z uprzednio przeprowadzonych prac obstugowych. W prognozowaniu uszkodzeń, uwzględniano takie parametry statku powietrznego, jak typ statku, jego operator, wiek, liczba godzin w powietrzu, liczba cykli lotów, typ silnika oraz miejsce stacjonowania. Prawdopodobieństwo wystapienia uszkodzeń wykorzystano jako wskaźnik do hierarchizacji zadań obstugi technicznej statku powietrznego. Przydatność proponowanej metodologii zweryfikowano i potwierdzono na przykładzie czterech różnych projektów.
\end{abstract}

Stowa kluczowe: konserwacja statków powietrznych, prognozowanie uszkodzeń, metody szczupłego utrzymania ruchu, systemy uczace się, logistyka części zamiennych.

\section{Introduction}

Service at a maintenance and repair organization (MRO) should be as short and as cost-effective as possible, while taking into account all safety standards. Regular inspections and preventive maintenance keep aircraft safety at an expected level [28]. Aircraft maintenance is a general term that includes aircraft checks that help assess aircrafts and the condition of their component parts. It can include short preflight checking or longer detailed checks of the aircraft and its component parts. Unplanned maintenance downtime causes flight service disruption, resulting in the loss of customer satisfaction for on-time performance [21]. Some component parts have a limited life, and when they expire, they should be replaced by new ones. Maintenance intervals and procedures are specified by the aircraft manufacturer and verified by aviation authorities. MROs have to follow strictly the prescribed procedures.
Aircraft maintenance is based on project-type work. Each aircraft that is being checked is regarded as an independent project. The customer who is bringing the aircraft in for maintenance wants all the work required based on the aircraft age, flight hours and cycles to be completed. All the required work is assembled in a work-package (WP), defined by the customer on the basis of aircraft manufacturer maintenance procedures. WP consists of job cards (JC) and job cards consist of task cards (TC). When an inspector performs some inspection, he signs off the respective task card. When all task cards of a particular job card are signed off, the job card can also be signed off. When all job cards are completed, the work-package is completed. New faults are often found during the aircraft inspection and need to be addressed during aircraft inspection. The number of discovered faults depends on the quality of previous maintenance activities, flight hours and cycles, the aircraft's usual operation location and other factors. Newly discovered faults most often dictate the work performed 
on a project. Repairing the faults within the project time frame requires additional spare parts and special tools. Any lack of spare parts or tools can cause a delay in a project in the range of several days or an increase of project costs, caused by urgent supply, which is unacceptable for both the customer and the MRO.

The maintenance service analysis according to lean methodology was conducted on a 10-day C-check [31]. C-check typically has to be performed after 7500 flight hours or 5000 flight cycles or 24 months from the previous check, whatever occurs first. It typically consists of 300 to 600 job cards. A systematic analysis of aircraft maintenance processes revealed that spare parts and tool logistics have a significant impact on the costs and time course of aircraft service activities [31]. Some other researchers report on similar conclusions [2, 13 and 23]. Additional analyses have shown that early information on faults is the main leverage for improved spare parts logistics. The assumption was that fault forecasts can be made from historic data on maintenance services in the past aircraft projects. With respect to aircraft parameters, such as aircraft age, flight hours and cycles, operator, aircraft type, engine type and operation location, it is possible to forecast some of the faults to a certain degree and prepare for them. With this objective in mind, an algorithm has been developed for fault forecasting and it was integrated into spare parts logistics and the whole aircraft maintenance projects.

\section{Literature survey}

\subsection{Aircraft maintenance}

A maintenance plan is made for the faults that reduce flight safety and incur high maintenance costs. It includes checks for safe and reliable component functioning [11 and 28]. Several authors focused on aircraft health monitoring and optimum maintaining periods planning [5, 9, 29, 34 and 43]. Aircraft maintenance is split into different types of inspection, consisting of specific tasks, depending on flight hours, flight cycles and how much time has passed since the latest check [28]. Optimizing aircraft maintenance planning is - among others discussed in the works of [16, 30 and 40]. In their aircraft inspection planning model [4] Baohui takes into account factors such as the human factor, type of inspection, type of aircraft, operation location and MRO. Bruno and co-authors compare the use of different aircraft maintenance planning techniques [6]. They share their focus on aircraft inspection planning, i.e., when a plane should be stopped and what checks should be performed during the forthcoming inspection. Maintenance of complex systems, such as aircraft, benefits vastly from an integrated approach to planning and scheduling of multiple activities, materials and resources. Investigations into current practices have shown that around 50 per cent of the total heavy maintenance workload is typically identified as part of inspections carried out during lay-up [36]. Li and co-authors propose innovative condition-based maintenance scheduling methodologies by integrating complex data processing, feature extraction, prognostic algorithm, and maintenance scheduling optimization. A numerical example shows how the aircraft reliability and health information can be integrated into the maintenance scheduling and planning optimization [26]. There are some specific ERP (Enterprise Resource Planning) software solutions that are upgraded for MRO specific needs [24].

Galar et al [12] propose a combined data mining-based methodology for condition-based maintenance considering condition monitoring data and historical maintenance management data. Gu, Zhang and Li present a non-linear programming model that forecasts demands, based on the aging of parts and the failure of installed parts [14]. Wang and Pham describe various models of maintaining and replacing component parts [42]. They mention replacement due to aging, periodic replacement, replacement due to failure, cost-limited repairs, time-limited repairs, scheduled maintenance, ad hoc maintenance and group maintenance. Each of the above models has its advantages and disadvantages. It has been demonstrated that a branch-and-price approach can be used to solve operational aircraft maintenance routing problem that the airlines face on a daily basis [37]. Lu et al propose a virtual maintenance environment, in which maintenance task virtual simulation can be conducted to support maintainability concurrent design of aircraft system [27].

Some of the authors have focused on the logistics of spare parts. MROs usually have expendable materials in stock. Due to differences in aircraft configurations and modification statuses, different contracts between customers and spare parts suppliers, and customers' wishes, components and other parts are borrowed or exchanged when they are required and as the need arises [31]. Due to the unpredictable nature of aircraft maintenance repair parts demand, MRO (Maintenance, Repair, Overhaul) business experience difficulties in forecasting and are currently looking for a superior forecasting solution. Several authors deal with techniques applicable to predicting spare parts demand [2, 13 and 23]. Most of the literature shows inefficiency of conventional forecasting methods, based on time series, for predicting such phenomena. Conventional methods inadequately reflect nonlinearity in the data, while artificial neural networks or a single artificial neuron do it well. Artificial intelligence techniques, artificial neural networks in particular, are the logical choice for further research [9].

The three main participants in air transport (aircraft manufacturers, operators and maintenance services) have mutually conflicting interests in making profit. Together with technological improvements, the use of new technology should bring economic benefits when compared to existing technologies [16]. Cohen and Wille propose a coordinated, data-driven approach for managing parts throughout the entire MRO service supply chain to improve the management of service part logistics. Improved part consumption forecasts for scheduled maintenance can be developed by taking into account causal factors, such as the plane and part age/history, as well as the known maintenance schedule of tasks for future checks of each airplane in the fleet [10]. The development of autonomic logistics, prognostic health management and distributed information systems are means of cost reduction and improving the maintenance of aircraft [7]. The framework proposed by Lee et al integrates simulation, multi-objective computing budget allocation and multi-objective evolutionary algorithms. The computational results show that, for the aircraft spare parts allocation problem, the framework is capable of finding non-dominated inventory and replacement policies with low average costs and high service levels [25]. Rasuo and Duknic report on a research, based on data, collected at general maintenance of military aircraft with the goal of reducing costs and shortening the overhaul cycle. Proposals for process optimization actions are primarily about improving the overhaul technology and supply system [33].

\subsection{Lean methods and aircraft maintenance}

The introduction of lean methods into aircraft maintenance requires the introduction of constant changes and the optimization of the aircraft maintenance process. The key is a comprehensive understanding of the processes and the maintenance processes. Lean thinking provides a systematic approach to identifying and eliminating waste through pull strategy in order to remain competitive in the global market [38 and 28]. In this context, any losses caused by the activities that generate direct or indirect costs, while not adding a value to the product and/or service from the point of view of the client, are designated as "waste" [38]. Womack and Jones [45] provide directions to set up guidelines, to cater the challenges that are encountered when a nonlean industrial organization tries to convert itself into a lean organization by means of five lean principles: value, value stream, flow, pull, and perfection, as the framework for an organization to understand the strategic approach of lean transformation. The terms are divided 
into "value adding" and "non-value adding activities" (waste): (1) Value adding activities (VAA) convert materials and/or information in the search to meet client's requirements and (2) Non-value adding activities (NVAA) are attributed to time, resource or space consuming, which do not add value to the product and/or service that shall be delivered to the client. Hence, it is essential to minimize NVAA within maintenance by implementing the lean tools [18 and 22]. The two key segments of introducing lean processes are: (i) to understand what represents added value for the end customer and (ii) creating added value. Lean maintenance is a method of discovering and eliminating unnecessary activities, as well as a method of improving the efficiency of processes [19 and 35].

There are some applications of lean methods into aircraft maintenance service. Stadnicka et al. demonstrate the use of the VSMbased (value stream mapping) methodology together with other tools in aircraft maintenance processes in minimizing the lead-time of maintenance services and, subsequently, minimizing the costs of maintenance services [41]. Based on VSM of the current state of the maintenance service process the following solutions were proposed: (i) Analyses of these activities that can be carried out in parallel; (ii) Creating a safety stock on the basis of a statistical analysis of unit's failures in the service company [41]. Kasava analysed the process of line maintenance and four main activities were identified. These were broken down into smaller sub activities and subsequently categorised into value adding and non-value adding activities [20]. Eliminating the unnecessary activities also contributes to cost reduction [3] because the main objective is to respond to the requirements and desires of the end customer as efficiently and economically as possible and with minimal effort, minimal workforce, minimal facilities and in the shortest possible time [17]. Lean thinking first requires specifying the value of a product or service. All processes not contributing to the end value of the product or service are considered waste. The key of lean thinking is eliminating waste and adding value for the customer [28].

A typical project in MRO organization was analysed through LEAN eyes. The results of this analysis encouraged the authors to conduct the research on aircraft fault forecasting. A 10-day C-check on Airbus A321 aircraft was taken as a sample check for lean analysis. The check itself was planned approximately a month in advance. Work-orders were checked and spare material was ordered one week before the start of the check [31]. The project analysis consist of: (i) Estimation of time-schedule for project milestones and project phases within the time given to the project. (ii) The existing main tasks were analysed in the sense of their duration and the ratio between VAA / NVAA was calculated. (iii) A survey was carried out with the main mechanics and heads of each work-shop. They were also asked about possible improvements for each waste or project deficiencies. During the project analysis all the implemented work activities were divided into two groups: VAA and NVAA group. It was found that almost two thirds of all the work is NVAA and just one third of the implemented work is VAA.

\section{The following activities were put into VAA group:}

- Inspections - On the basis of these activities the customer is allowed to extend the aircraft airworthiness.

- Modifications - After the accomplishment of the requested modification the customer expects positive impact and consequently lover operational costs and therefore these activities also represent VAA.

- Eliminating incoming defects - At the time of the check the customer knew about them and would like to eliminate them.

- Eliminating of new findings / defects, discovered during the check

\section{Into NVAA group belong all activities in following sub-groups:}

\section{- Acceptance}

- Preparation

- Close-up

- Tests

Further on, unnecessary project events, which have a negative impact on the used working hours and consequently on the final project price, were analysed. The most exposed events, irrespective of the group into which they belong, were:

- Tooling loan was planned for the first day of the check, although it was eventually needed on the third day of the check.

- Due to simultaneous start of several projects (aircraft checks) on the same day, there was a lack of manpower on the first days of the project.

- Due to the aircraft position in a wrong hangar some work-shops were not close to the aircraft. As a result, much transportation of parts and man-power motions were required during the inspection and the re-assembly phase of the project.

- A lack of some consumable material was found in the middle of the check, which had to be additionally ordered on a higher priority level and was consequently more expensive.

- In the re-installation phase of the project a few man-hours were lost due to the waiting for the material. The particular material could not be released from the store due to certificate issues.

- Due to the aircraft flight hours/flight cycles and job cards (inspections), known prior to the project, some spare material was ordered in advance on the basis of previous experiences and expectations, but was later not used during the project.

The analysis has shown that spare parts logistics has potential for improvement. When spare parts and tools are required, the required shipping speed depends on the time available to finish the project. In terms of the available time, orders are placed according to the following priority list: (5) - Normal, (4) - Urgent, (3) - Critical, (2) -Work on Project Aborted (work on the aircraft has been stopped due to a shortage of material), (1) - Aircraft on Ground (AOG -aircraft has been grounded due to a shortage of material). Higher priority means faster and more expensive shipping. When there is enough time to remedy a fault (a fault was found at the beginning of the inspection), the order is given the 5 - Normal priority and the delivery will be cheaper. The MRO's and the customer's objective is to order materials soon enough with the 5 - Normal priority. However, this is only possible when information on the required material is recognized quickly and the material is ordered sufficiently soon. It is possible to obtain early information on the required material with an early inspection check.

The inspectors' personal experiences are the easiest but usually less optimal way to set the order of jobs to be completed within an aircraft check. As such, this way is limited by the person's abilities. Because the inspector himself or herself sets the order of tasks - without taking into account all aircraft parameters - the discovery of faults is distributed along the entire working process. Often, some faults are found at the beginning of the inspection, which is then followed by a period of finding no faults. At the end of the prescribed tasks, the number of discovered faults increases again.

With the implementation of some tools for optimization, such as fault forecasting, some of the significant wastes can be eliminated from the process and spare material, the required tooling and manpower can be planned in advance more reliably. Aircraft fault forecasting of maintenance service on the basis of historic data and aircraft parameters is presented in the next sections of this paper. Some other long-term activities for waste reduction, related to investments into hanger infrastructure and improved internal logistics, are not included in this report. 


\section{Research methodology}

The analysis of maintenance process has shown the potential for service time and cost reduction in improving the supply of spare parts and tooling. The newly found faults represent a major variable in planning and executing service activities. Better forecasting of these faults offers the potential for quicker execution of aircraft service activities and lower logistics costs. The hypothesis is: historic data of maintenance services in recent years and aircraft parameters can be used for improved prediction on what faults will be found during the service. Early information on requested spare parts and tooling will enable prompt and more cost-efficient spare parts logistics. The solution shall enable continuous learning and incremental model upgrade with new cases of maintenance services. The initial model for the fault forecast algorithm is presented in the Fig. 1.

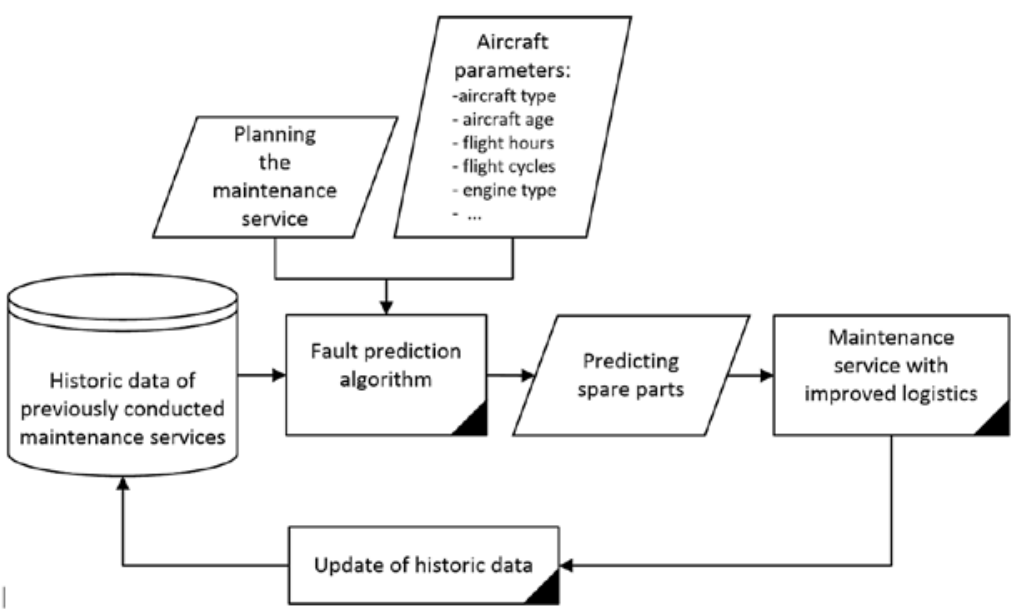

Fig. 1. The initial model for the fault prediction algorithm

At the beginning of the research project, there was a question what kind of machine learning tool shall be applied to a reliable prediction model. The presented model is the result of several iterations and data analyses. Already at the beginning there was a request that the model usability had to be validated by data from several new maintenance services. The initial prediction was that aircraft parameters, such as aircraft age, flight hours and cycles will contribute to the reliability of the model. The data analysis and validation will show a more detailed influence of particular aircraft parameters.

The surveyed literature is focused in most cases on the monitoring and planning of inspections, i.e., when to stop an airplane and what inspections to perform during the check. This article focuses on performing the maintenance project in the shortest and cheapest way. The aircraft parameters and probability factors were introduced, and historical data were processed by means of machine learning. The possibility of using regression analysis, neural networks [32] and genetic algorithms [39] was analysed first. Regression analysis is not suitable due to attribute data (operation location, engine types, operators, aircraft type). Some of the authors report on promising results using neural networks for predicting spare parts at maintenance service [9 and 23]. In our case we have got good results by applying relatively simple calculation of probability. Our wish was to do make spare part prediction model transparent and with traceability from historic data to predictions. In his work, Carbonneau et al investigated the applicability of advanced machine learning techniques for supply chain demand forecasting; the conclusion was that machine learning techniques do not show significantly better performance than linear regression [8]. On the basis of literature review, a generally applicable method for spare parts prediction cannot be specified. The optimal solution depends on the nature of the problem; whether it is linear or non-linear.

Witten defines system learning as a change in system behaviour in the direction that enables an easier/better execution of a task in the future [44]. Machine learning methods are used to forecast faults on aircrafts on the basis of previous checks - data is transformed into information [15]. Many machine learning studies cover the development of algorithms for specific problems and specific data [1]. Machine learning can be divided into supervised learning, unsupervised learning and reinforcement learning.

In his work, Harrington [15] states seven steps of machine learning:

1) collecting data (collecting data and patterns vital to achieve the goal),

2) preparing input data (data processing and selecting appropriate data format),

3) analysing input data (data analysis, recognizing patterns in the data, and recognizing exceptions),

4) validating data correctness (in the case of non-automated systems, to prevent incorrect data entering the system),

5) algorithm learning (inputting the available data into the algorithm),

6) algorithm testing (testing the performance of the algorithm), and

7) applying the knowledge (practical use).

The suggested steps of machine learning were used to forecast faults during aircraft service checks.

\subsection{Aircraft parameters and probability factors}

Aircraft parameters provide the aircraft's basic features, therefore it was assumed that they represent the key link to fault forecasting. They were selected together with the assistance of experts and are based on years of aircraft maintenance experience. The selected aircraft parameters are as follows:

Aircraft type

Operator

Aircraft age

Flight hours

Flight cycles

Engine type

Operation location - the area where the aircraft spends most of the time

The aircraft parameters served as a basis for defining probability factors. A probability factor represents the ratio between the number of discovered faults and the number of performed checks for the particular job.

$$
p=\frac{N_{1}}{N_{2}}
$$

Where:

$N_{1}$ - number of findings on particular job card

$N_{2}$ - number of issued job cards

Probability factor $p$ values can be expressed as follows:

a) »-«-a particular part/area has not been checked yet, so no fault has been discovered yet.

b) $» p=0 \ll-$ a particular part/area has been checked, but no faults were discovered during previous checks.

c) $» 0<p<1 \ll-$ a particular part/area has been checked, and faults were discovered during previous checks. 
d) $» p>1 \ll-$ a particular part/area has been checked, and several faults were discovered within a single check.

Factor values are used to set the order of jobs to do. Factor values are defined according to the parameters of the aircraft that is being inspected. Seven probability factors have been defined, and they are shown in Table 1 . Using equation 2 , the aggregate probability factor is calculated from partial probability factors. In principle each probability factor contributes an equal share to the aggregate factor, therefore $1 / 7$ ue to seven probability factors.

$$
p=\frac{p_{1}+p_{2}+p_{3}+p_{4}+p_{5}+p_{6}+p_{7}}{N_{3}},
$$

Where:
$p_{1}$ - Probability factor for aircraft type
$p_{2}$ - Probability factor for operator
$p_{3}$ - Probability factor for aircraft age
$p_{4}$ - Probability factor for aircraft flight hours
$p_{5}$ - Probability factor for aircraft flight cycles
$p_{6}$ - Probability factor for engine type
$p_{7}$ - Probability factor for operation location
$N_{3}$ - number of probability factors $\left(N_{3}=7\right)$

Table 1. Probability factors

\begin{tabular}{|c|l|c|c|}
\hline No. & \multicolumn{1}{|c|}{ Probability factor } & Mark & Note \\
\hline 1 & Aircraft type & $p_{1}$ & $\frac{N_{11}}{N_{21}}$ \\
\hline 2 & Operator & $p_{2}$ & $\frac{N_{12}}{N_{22}}$ \\
\hline 3 & Aircraft age & $p_{3}$ & $\frac{N_{13}}{N_{23}}$ \\
\hline 4 & Aircraft flight hours & $p_{4}$ & $\frac{N_{14}}{N_{24}}$ \\
\hline 5 & Aircraft flight cycles & $p_{5}$ & $\frac{N_{15}}{N_{25}}$ \\
\hline 7 & Engine type & $p_{6}$ & $\frac{N_{16}}{N_{26}}$ \\
\hline
\end{tabular}

Where:

$N_{11}$ - number of findings on particular job card for specific aircraft type

$N_{21}$ - number of issued job cards for specific aircraft type

$N_{12}$ - number of findings on particular job card for specific operator

$N_{22}$ - number of issued job cards for specific operator

$N_{13}$ - number of findings on particular job card for specific aircraft age

$N_{23}$ - number of issued job cards for specific aircraft age

$N_{14}$ - number of findings on particular job card for specific flight hours

$N_{24}$ - number of issued job cards for specific flight hours

$N_{15}$ - number of findings on particular job card for specific flight cycles
$N_{25}$ - number of issued job cards for specific flight cycles

$N_{16}$ - number of findings on particular job card for specific engine type

$N_{26}$ - number of issued job cards for specific engine type

$N_{17}$ - number of findings on particular job card for specific flight location

$N_{27}$ - number of issued job cards for specific flight location

In the next section, the proposed methodology is integrated into the fault prediction model and later the model is validated.

\section{Fault forecasting model and job cards priority list setting}

The fault forecasting model is integrated into the aircraft maintenance project as presented in Fig. 2. The contract with the customer and the work package are the background for project planning - for the job cards priority list. The fault forecasting algorithm enables fine project scheduling and optimized spare parts logistics.

Maintenance jobs are conducted according to the job cards priority list. Several iobs can be executed concurrently by several inspec-

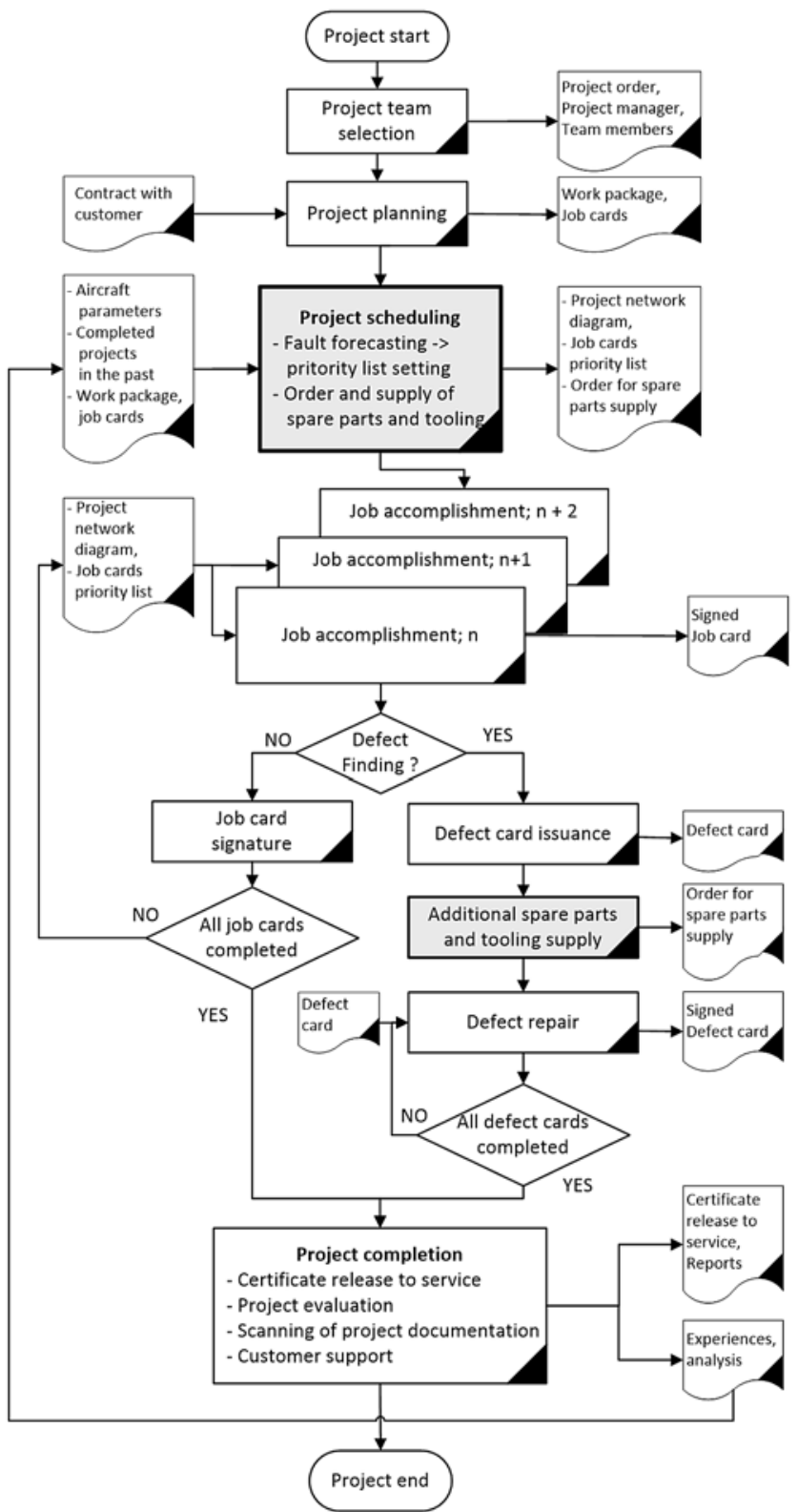

Fig. 2. Position of the fault forecasting in the aircraft maintenance service project process model 
tors. If an inspector finds a defect, a defect card is issued and in some cases additional spare parts and tooling need to be supplied before the defect is repaired. Early information on requested spare parts is essential; therefore it is important to do the job cards with higher fault probability first. Once all defects have been repaired and all job cards are completed the activities for project conclusion can start. At the end of the project new findings (newly discovered faults) are included in the history database, which teaches the system for future projects (Fig. 2).

\subsection{Model for fault forecasting and calculating the order of job priorities}

A model for fault forecasting and setting the order of job priorities is shown in Fig. 3. In Fig. 2, this activity is called "Project scheduling". Input data for the calculation model are as follows:

- Aircraft manufacturer's list of job cards - list of all job cards prescribed by the aircraft manufacturer,

- Historic data from previous projects - information on the number of issued job cards and the number of discovered faults during previous projects,

- Aircraft parameters for each project - basic project data that include seven parameters (aircraft type, operator, aircraft age, aircraft flight hours, aircraft flight cycles, engine types and operation location), the project work order number and the date of the completion of the service project,

- Work-package - list of selected job cards from the manufacturer's list of cards that should be completed within the project according to the aircraft flight hours, flight cycles and aircraft age. This job cards list is defined by the customer.

on a particular project. The input data for calculation are as follows: (i) Work package with job cards list, (ii) Parameters of the aircraft coming for inspection, and (iii) the pre-processed data from previous projects prepared in step one (Fig. 3). Considering the number of discovered faults on previous projects the software calculates factors for the probability of discovering a fault within a particular job card. Job cards are then classified according to the size of the probability factor. Those with the highest probability of discovering faults are placed at the beginning of the job cards priority list.

Once a project has finished, the new data on the recently completed project are analysed and attached to the "History" database. The database is updated after each project, which allows the system to learn and offers more accurate solutions. The volume of data will increase with the number of completed projects. This will update the calculation system and improve it.

\subsection{Attaching values to probability factors}

An analysis of the accuracy model for calculating the aggregate probability factor was performed. The analysis was conducted on four completed projects that were not included in the "History" database. Following a systematic variation of weights and checking the target function the weights for individual parameters were optimized. The weights for each parameter were varied in the programmed calculation experiment in the range between 0 and 3 with step 0.5 . The best results according to equation 4 were obtained using the equation with the following weights for individual parameters:

- Weight for the probability factor "Aircraft type": 2.0

- Weight for the probability factor "Operator": 1.0

- Weight for the probability factor "Age": 1.0

- Weight for the probability factor "Flight hours": 0.5

- Weight for the probability factor "Flight cycles": 0.5

- Weight for the probability factor "Engine type": 2.0

- Weight for the probability factor "Operation location": 1.0

The new equation 3 for the calculation of the aggregate probability factor is as follows:

$$
p=\frac{2 p_{1}+p_{2}+p_{3}+0.5 p_{4}+0.5 p_{5}+2 p_{6}+p_{7}}{N_{3}} .
$$

Target function that evaluates the job cards priority list is calculated according to the equation 4. Sequence (Job_card ${ }_{i}$ ) represents the sequence position of the Job_card ${ }_{i}$ in the sorted priority list which is the result of the fault forecasting algorithm. Function Fault (Job_card ${ }_{i}$ ) has value 1 if a fault is found and value 0 if a

Job priority list is created in two steps, as shown in Fig. 3. In the first step the data from the first three databases need to be processed. For each job card, it is counted how many times it has been issued and how many faults have been discovered during the maintenance services in the past. This operation needs to be done each time when history database is upgraded with the data from one or several finished projects.

In the step two the fault probability is calculated for each job card. Work package is available already before the aircraft arrives, so the pre-described job cards are also available in advance. This process is followed by calculating the order in which the jobs will be performed fault at Job_card $d_{i}$ is not found. Function Fault values are determined after the completion of the maintenance project. It is preferred that the job cards where the fault has been found are in the first third of the priority list. Lower value of the target function means that the fault forecasting was good.

$$
\text { Target_function }=\sum_{i=1}^{N} \operatorname{Sequence}\left(J_{o b}{ }_{-} \text {card } d_{i}\right) \cdot \text { Fault }\left(J_{o b}{ }_{-} \operatorname{card}_{i}\right)
$$

At first sight, the result is surprising because it is expected that the (i) "Flight hours" and (ii) Flight cycles" parameters would yield 
the best result, which means that the jobs with the highest number of discoveries would be performed at the beginning of the inspections. However, these two parameters perform the worst in the calculation of the sum of job order numbers - the jobs with a higher number of discoveries were performed later in the inspection phase. As a result, the probability factors of the above two parameters were weakened by a weight of 0.5. Calculating the sum of the job order numbers showed that the best results were obtained from the (i) "Aircraft type" and (ii) "Engine type" parameters. As a result, these two parameters were given a weight of 2 .

If the best results were obtained by the "Flight hours" and "Flight cycles" parameters, it would mean that more flight hours and more flight cycles (within a particular job card) result in a larger number of discovered faults. However, because aircraft inspection schedules are based on the number of flight hours, flight cycles and the period since the previous inspection, the faults - associated with these two parameters - are fixed promptly and do not accumulate with an increasing

Table 2. Parameters of the analysed projects

\begin{tabular}{||c|c|c|c|c|c|c|c||}
\hline \hline PROJECT & $\begin{array}{c}\text { AIRCRAFT } \\
\text { TYPE }\end{array}$ & $\begin{array}{c}\text { OPERA- } \\
\text { TOR }\end{array}$ & AGE & $\begin{array}{c}\text { FLIGHT } \\
\text { HOURS }\end{array}$ & $\begin{array}{c}\text { FLIGHT } \\
\text { CYCLES }\end{array}$ & $\begin{array}{c}\text { ENGINE } \\
\text { TYPE }\end{array}$ & LOCATION \\
\hline I & Type C & $\mathrm{J}$ & 3 & 5262 & 1722 & Engine B & Europe \\
\hline II & Type B & $\mathrm{J}$ & 5 & 14264 & 5486 & Engine A & Europe \\
\hline III & Type A & $\mathrm{E}$ & 16 & 42617 & 31586 & Engine B & Europe \\
\hline IV & Type B & $\mathrm{E}$ & 24 & 58904 & 47370 & Engine B & Europe \\
\hline
\end{tabular}

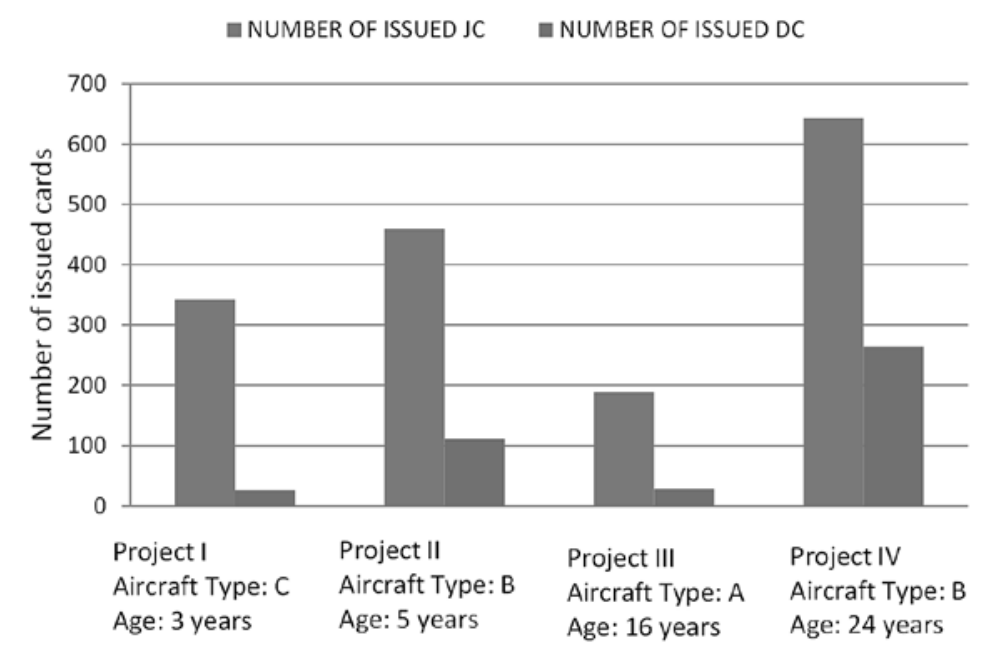

Fig. 4. Number of issued job cards (JC) and defect cards (DC) for each project number of flight hours and flight cycles. Consequently, it makes sense not to strengthen these two parameters. In contrast, the "Aircraft type" and "Engine type" parameters are strengthened because the obtained results show that they have the most significant effect on the sum of job order numbers.

\section{Algorithm validation}

To analyse the current condition with an emphasis on the timeline of fault discovery, four completed projects were included in the analysis. The four projects are named "Project I", "Project II", "Project III" and "Project IV". The parameters of the analysed projects are shown in Table 2.

Figure 4 shows the number of issued job cards and defect cards in relation to aircraft age and aircraft type in the analysed projects.

Figures 5 and 7 show the timeline of discovering faults (issuing defect cards), according to the current method of completing jobs, as determined by inspectors, based on their experience. Figures 6 and 8 show the timeline of discovering faults (issuing defect cards) according to the new, optimized method of completing jobs using probability factors. The $\mathrm{x}$ axis shows the sequence of the accomplished jobs. The y-axis shows the number of issued defect cards per job card. An analysis of the current situation in completing jobs revealed that faults are being discovered along the entire timeline of work. Using probability factors, the discovered faults move to the left, closer to the beginning of work. Figures 5, 6, 7 and 8 graphically present Projects II and IV. Significant improvements were achieved in Projects I and III as well. Validation confirmed the efficiency of the algorithm; the fault forecast is accurate in all four examples of airplanes aged between 3 and 24 years.

\section{Conclusion}

An aircraft fault forecasting model has been developed on the basis of aircraft parameters and previously completed service projects. The model makes it possible to set the order of inspections according to the criterion of the highest probability of discovering a fault. Its use reduces the total time required to complete the service on an aircraft and reduces logistics costs for spare parts and the required tools. The collected data on the frequency of faults also serve as important feedback for aircraft manufacturers.

Probability factors are the ratio between the number of discovered faults and the number of executed inspections. They are the basis for a fault forecasting model. To calcu-

\section{Sequence of Accomplished Jobs - Project II - Current Situation}

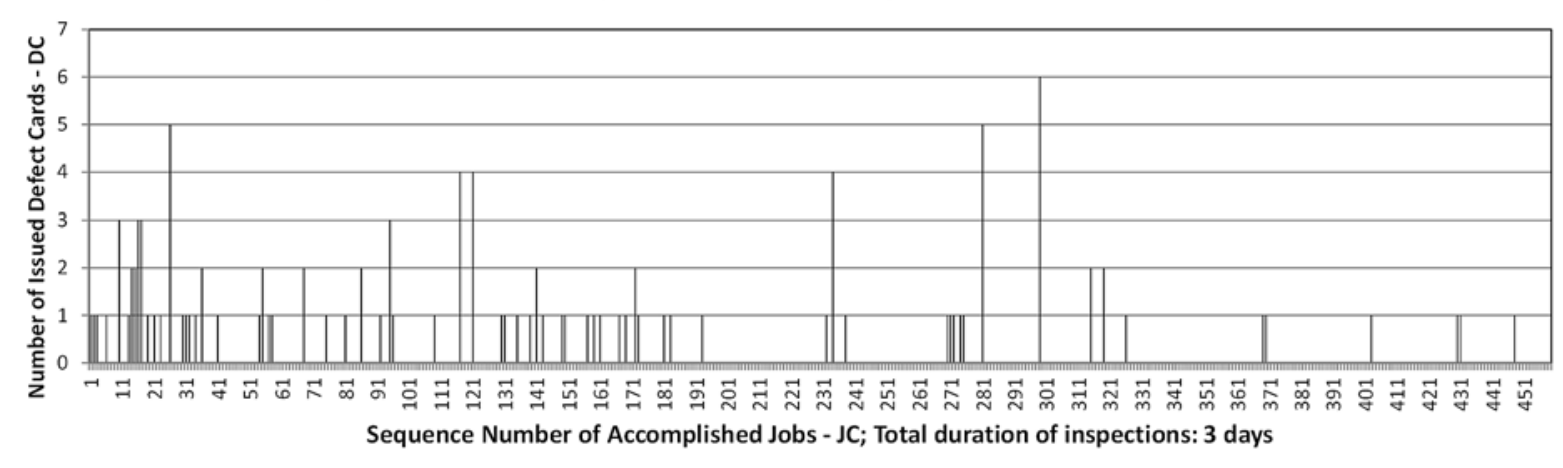

Fig. 5. Comparison of the timeline of issuing defect cards for the analysed project II. Sequence of accomplished jobs as determined by inspectors 
Sequence of Accomplished Jobs - Project II - New Probability Factor

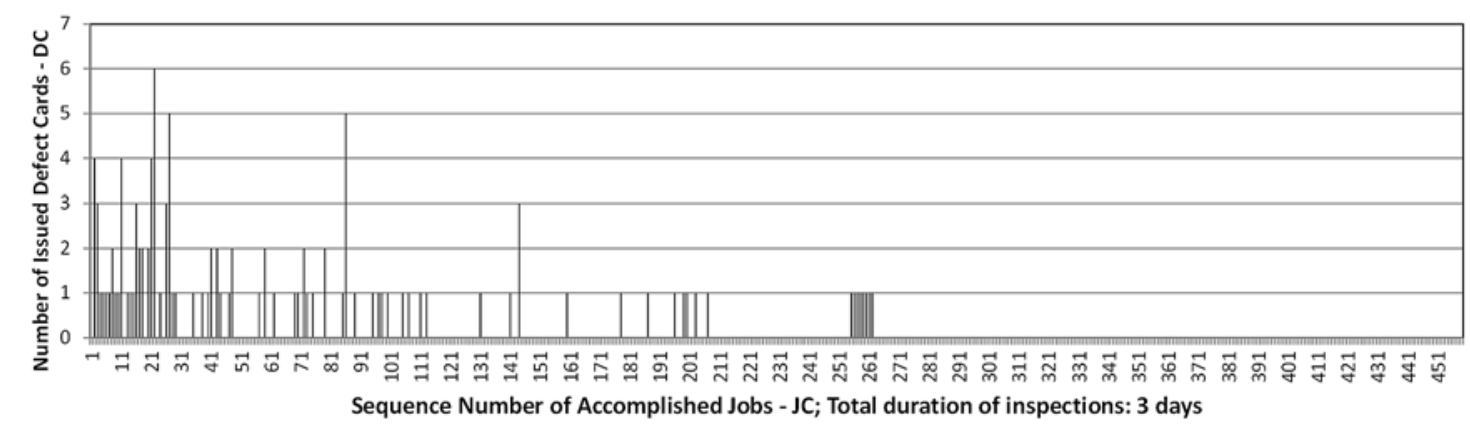

Fig. 6. Comparison of the timeline of issuing defect cards for the analysed project II. Sequence of accomplished jobs according to optimized method, using probability factor.

\section{Sequence of Accomplished Jobs - Project IV - Current Situation}

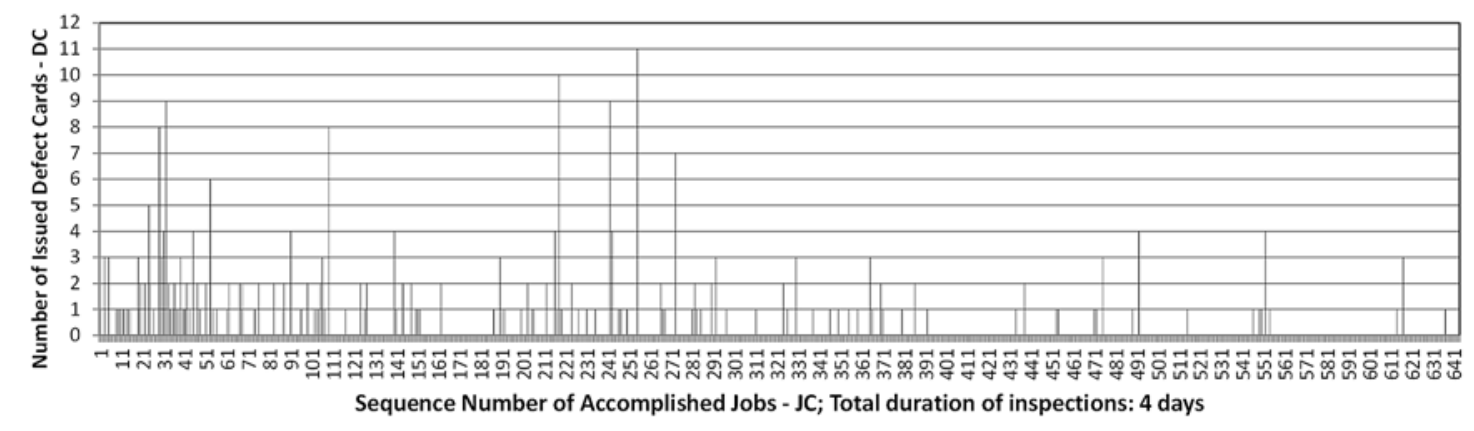

Fig. 7. Comparison of the timeline of issuing defect cards for the analysed project IV. Sequence of accomplished jobs as determined by inspectors

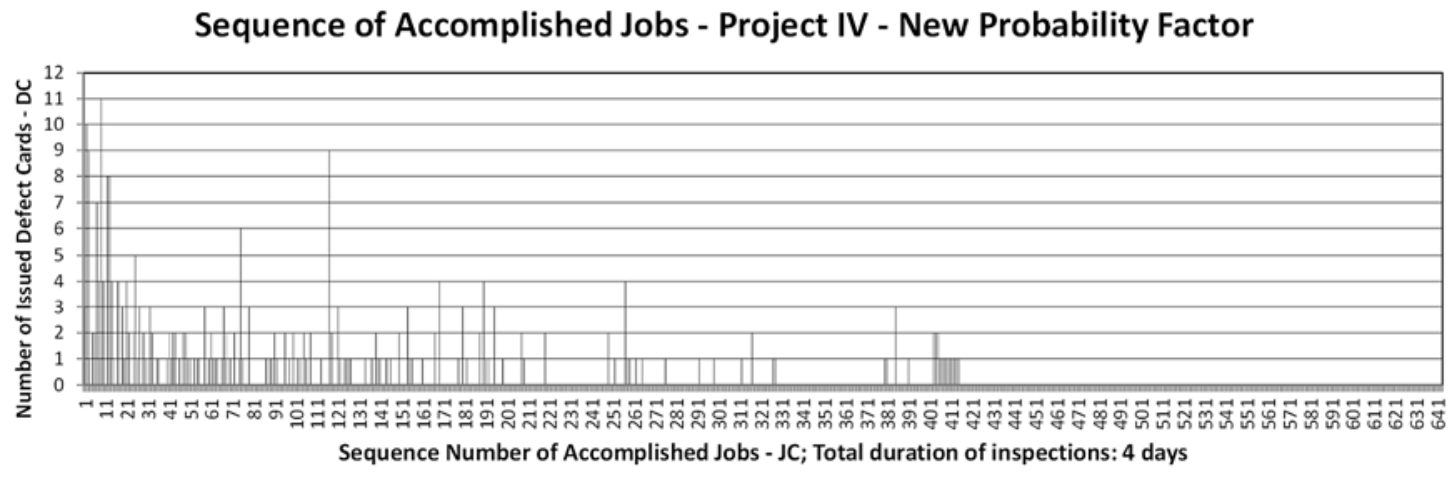

Fig. 8. Comparison of the timeline of issuing defect cards for the analysed project IV. Sequence of accomplished jobs according to the optimized method, using probability factor

late probability factors, an algorithm has been developed. It takes into account aircraft parameters and information on the number of discovered faults on previously completed maintenance projects. The sequence of jobs is determined by the aggregate probability factor, composed of the probability factors of individual parameters, such as flight hours, flight cycles, operators, aircraft age, engine type, aircraft type and the location the aircraft spent most of its operation time, and is further optimized with aircraft parameters weights. The sequence of jobs is determined by the size of the aggregate fault forecasting probability factor. The model for calculating the execution of jobs includes a feedback loop, which allows model learning with new information from the most recently completed maintenance projects. In this way, the calculation method is updated after each completed project, which in turn provides more accurate results. Taking into account a typical seven-day aircraft $\mathrm{C}$ check, consisting of approximately 300 jobs, algorithm validation revealed that arranging the jobs can shorten the project by one day, which is $14 \%$ of the total duration of the project. Earlier orders of materials and consequently lower shipping costs also significantly reduce the costs of the project. The presented machine learning methodology is therefore a significant tool for more efficient operational management of aircraft maintenance projects.

\section{Acknowledgment}

The authors would like to thank the company Adria Airways Tehnika, Aircraft Maintenance, part of Linetech, Poland for support of the research project. 


\section{References}

1. Allison L. Types and Classes of Machine Learning and Data Mining. Clayton, Victoria: Monash University, 2003.

2. Altay N., Litteral L.A. (ed.) Service parts management: Demand forecasting and Inventory Control, Springer-Verlag, London 2011, https:// doi.org/10.1007/978-0-85729-039-7.

3. Amirjabbari B., Bhuiyan N. An Application of a Cost Minimization Model in Determining Safety Stock Level and Location. World Academy of Science, Engineering and Technology 2011; 79: 797-806.

4. Baohui J., Chunhui X., Yaohua L. Study on Optimization Method of Aircraft Maintenance Plan Based on Longest Path. Journal of Applied Sciences 2013; 13(16): 3354-3357, https://doi.org/10.3923/jas.2013.3354.3357.

5. Bazargan M. An optimization approach to aircraft dispatching strategy with maintenance cost - A case study. Journal of Air Transport Management 2015; 42: 10-14, https://doi.org/10.1016/j.jairtraman.2014.07.008.

6. Bruno V., Garcia L., Nocco S., Quer S. Stressing Symbolic Scheduling Techniques within Aircraft Maintenance Optimization. Journal on Satisfiability, Boolean Modeling and Computation 2008; 5: 83-110.

7. Byer B., Hess A., Fila L. Writing A Convincing Cost Benefit Analysis to Substantiate Autonomic Logistics. IEEE Aerospace Conference, 2001; 6: 3095-3103, https://doi.org/10.1109/AERO.2001.931327.

8. Carbonneau R., Laframboise K., Vahidov R. Application of machine learning techniques for supply chain demand forecasting. European Journal of Operational Research 2008; 184: 1140-1154, https://doi.org/10.1016/j.ejor.2006.12.004.

9. Chen D., Wang X., Zhao J. Aircraft Maintenance Decision System Based on Real-time Condition Monitoring. IWIEE, Procedia Engineering 2012; 29: 765 - 769, https://doi.org/10.1016/j.proeng.2012.01.038.

10. Cohen M. A., Wille J.-H. Implications for Service Parts Management in the Rapidly Changing Aviation MRO Market. Hamburg: Helmut Schmidt University, 2006.

11. Dekker R. Applications of maintenance optimization models: a review and analysis. Reliability Engineering and System Safety 1996; 51: 229-240, https://doi.org/10.1016/0951-8320(95)00076-3.

12. Galar D., Gustafson A., Tormos B., Berges L. Maintenance Decision Making based on different types of data fusion. Eksploatacja i Niezawodnosc - Maintenance and Reliability 2012; 14 (2): 135-144.

13. Ghobbar A.A., Friend C.H., Evaluation of forecasting methods for intermittent parts demand in the field of aviation: a predictive model, Computers \& Operation research, 2003: 2097-2114, https://doi.org/10.1016/S0305-0548(02)00125-9.

14. Gu J., Zhang G., Li K. W. Efficient aircraft spare parts inventory management under demand uncertainty. Journal of Air Transport Management 2015; 42:101-109, https://doi.org/10.1016/j.jairtraman.2014.09.006.

15. Harrington P. Machine Learning in Action. Shelter Island: Manning, 2012.

16. Hölzel N. B., Schröder C., Schilling T., Gollnick V. A Maintenance Packaging and Scheduling Optimization Method for Future Aircraft. Air Transport and Operations Symposium, 2012; 1-11.

17. Jasiulewicz - Kaczmarek M. Integrating Lean and Green Paradigms in Maintenance Management, The International Federation of Automatic Control, Cape Town, South Africa. August 24-29, 2014: 4471-4476.

18. Jasiulewicz-Kaczmarek M. Sustainability: Orientation in maintenance management: Case study. In: Golinska P, editor. EcoProduction and logistics, London: Springer; 2013: 135-154, https://doi.org/10.1007/978-3-642-23553-5_9.

19. Johnson M. E., Dubikovsky S. I. Incorporating Lean Six Sigma into an Aviation Technology Program. West Lafayette, Indiana: Purdue University, 2008.

20. Kasava N. K., Yusof N. M., Khademi A., Saman M.Z.M. Sustainable Domain Value Stream Mapping (SdVSM) Framework Application in Aircraft Maintenance: A Case Study. 12th Global conference on sustainable manufacturing: Procedia CIRP 2015; 26: 418-423.

21. Kipli J, Toyli J, Vepsalainen A. Cooperative Strategies for the Availability Service of the Repairable Aircraft Components. International Journal of Production Economics 2009; 117(2): 360-370, https://doi.org/10.1016/j.ijpe.2008.12.001.

22. Kolanjiappan S., Maran K. Lean Philosophy in Aircraft Maintenance. Journal of Management Research and Development (JMRD) 2011; 1 (1): $27-41$.

23. Kozik P., Sęp J. Aircraft engine overhaul demand forecasting using ANN, Management and Production Engineering Review 2012; 3 (2): 21-26.

24. Lam MD. ERP for MRO: An Alternative Perspective from Package Programs to Niche Providers. Overhaul and Maintenance 2008; 14(5): 36-43.

25. Lee L. H., Chew E. P., Teng S., Chen Y. Multi-objective simulation-based evolutionary algorithm for an aircraft spare parts allocation problem. European Journal of Operational Research 2008; 189: 476-491, https://doi.org/10.1016/j.ejor.2007.05.036.

26. Li Z., Guo J., Zhou R. Maintenance Scheduling Optimization Based on Reliability and Prognostics Information. Conference: 2016 Annual Reliability and Maintainability Symposium (RAMS), https://doi.org/10.1109/RAMS.2016.7448069.

27. Lu Z., Zhou J., Li N. Maintainability fuzzy evaluation based on maintenance task virtual simulation for aircraft system. Eksploatacja i Niezawodnosc - Maintenance and Reliability 2015; 17 (4): 504-512, https://doi.org/10.17531/ein.2015.4.4.

28. Murphy S. The Status of Lean Implementation within South African Aircraft Maintenance Organizations. Johannesburg: University of the Witwatersrand, 2011.

29. Papakostas N., Papachatzakis P., Xanthakis V., Mourtzis D., Chryssolouris G. An approach to operational aircraft maintenance planning. Decision Support Systems 2010; 48: 604-612, https://doi.org/10.1016/j.dss.2009.11.010.

30. Pleumpirom Y., Amornsawadwatana S. Multiobjective Optimization of Aircraft Maintenance in Thailand Using Goal Programming: A Decision-Support Model, Advances in Decision Sciences. 2012; 2012: 1-17.

31. Pogačnik B., Tavčar J., Duhovnik J. Application of lean methods into aircraft maintenance processes. Transdisciplinary lifecycle analysis of systems: ISPE Inc. Int. Con. on CE. Delft: 2015; 259-268.

32. Potočnik P., Strmčnik E., Govekar E. Linear and Neural Network-based Models for Short-Term Heat Load Forecasting. Strojniški vestnik Journal of Mechanical Engineering 2015; 61 (9): 543-550.

33. Rasuo B., Duknic G. Optimization of the aircraft general overhaul process. Aircraft engineering and aerospace technology 2013; 85 (5): 
343-354, https://doi.org/10.1108/AEAT-02-2012-0017.

34. Rodrigues L. R., Pordeus Gomes J. P., Bizarria C. de O., Harrop Galvão R. K. Using Prognostic System and Decision Analysis Techniques in Aircraft Maintenance Cost-Benefit Models. IEEE Aerospace Conference, 2010; 1-7.

35. Sahay C., Shetty D., Ghosh S., Islam M., Turner M. Optimization of Assembly and Disassembly of GP7200 Engine. ASME International Mechanical Engineering Congress and Exposition 2013; 3: 1815-1826.

36. Samaranayake P, Kiridena S. Aircraft Maintenance Planning and Scheduling: An Integrated Framework. Journal of Quality in Maintenance Engineering 2012; 18(4): 432-453, https://doi.org/10.1108/13552511211281598.

37. Sarac A., Batta R., Rump C. M. A branch-and-price approach for operational aircraft maintenance routing. European Journal of Operational Research 2006; 175, 1850-1869, https://doi.org/10.1016/j.ejor.2004.10.033.

38. Savhnay R, Kannan S, Li X. Developing a value stream map to evaluate breakdown maintenance operations. Int J Industrial and Systems Engineering 2009; 4(3): 229-240, https://doi.org/10.1504/IJISE.2009.023539.

39. Slak A., Tavčar J., Duhovnik J. Application of Genetic Algorithm into Multicriteria Batch Manufacturing Scheduling. Strojniški vestnik Journal of Mechanical Engineering 2011; 57, 2: 110-124.

40. Sriram C., Haghani A. An optimization model for aircraft maintenance scheduling and re-assignment. Transportation Research Part A 2003; 37: 29-48, https://doi.org/10.1016/S0965-8564(02)00004-6.

41. Stadnicka D., Ratnayake R.M.C. Enhancing aircraft maintenance services: a VSM based case study. Procedia Engineering, 2017; 182: 665672, https://doi.org/10.1016/j.proeng.2017.03.177.

42. Wang H., Pham H. Reliability and Optimal Maintenance. Springer Series in Reliability Engineering series, London: Springer, 2006.

43. Wazny M., Wojtowicz K. The analysis of the military aircraft maintains system and the modernization proposal. Eksploatacja i Niezawodnosc - Maintenance and Reliability 2008; 3: 4-11.

44. Witten I.H., Frank E., Hall M.A. Data Mining, Practical Machine Learning Tools and Techniques. Third Edition. Burlington: Morgan Kaufmann Publishers, 2011.

45. Womack JP, Jones DT. Lean thinking: Banish waste and create wealth in your corporation. New York: Simon and Schuster, 2010.

\section{Borut POGAČNIK}

Adria Airways tehnika

Zg. Brnik 130h

SI-4210 Brnik, Slovenia

\section{Jože DUHOVNIK \\ Jože TAVČAR}

University of Ljubljana

Faculty of Mechanical Engineering

Aškerčeva 6

SI-1000 Ljubljana, Slovenia

E-mail: Joze.Duhovnik@lecad.fs.uni-lj.si, Borut.Pogacnik@aateh.si, Joze.Tavcar@lecad.fs.uni-lj.si 